\title{
A Reading of the Third “Vespers” by Louise Glück
}

\author{
Muhammad Dirgantara Esa Valentino Am \\ mdirgant@uchicago.edu \\ Master of Arts Program in Humanities, University of Chicago, U.S.A.
}

\begin{abstract}
This paper presents a reading of the third "Vespers," a poem by Louise Glück collected in The Wild Iris, a book of poem sequence spoken by four different voices, dealing with the fact of human existence in the world, especially in terms of human existential suffering. To this date, this award-winning book has been considered by many to be among the poet's greatest achievements. This being the case, there have been so few detailed readings of the 54 poems constituting the book, however. Most of the existing scholarships on the poems are topic-centered rather than poem-centered. This article attempts to make its contribution to this by presenting a close reading of one of the poems, which is especially central to this polyphonic book both thematically and structurally. Assuming the critical premises and the analytical procedure of Helen Vendler, whose focus is on a poem's intrinsic elements and its relations to its thematic features, the paper discusses the third "Vespers"'s theme as expressed by both its obvious and minute features. By analyzing the poem's title, body, internal structure, diction, tense, mechanic, rhythm, syntax, and imagery, the paper concludes that the poem expresses and dramatizes, through the obvious and minute details, the perennial theme of human's pining for explanation about his/her discontent, which in the cosmos of the poem is directed to God, and its attendant feelings of doubt and conviction as a result of having to come up with his/her own answer as the one who holds the definite answer stays silent.
\end{abstract}

Keywords: The Wild Iris, Louise Glück, "Vespers", content, forms

\section{Introduction}

The Wild Iris is a poem sequence consisting of 54 free-verse pieces. These poems are spoken, in turn, by four different voices, namely a human speaker, various vegetation, an anthropomorphic God, and an objective speaker, deal with such perennial themes as mortality, suffering, and pining. The book is among Glück's major achievements as many have noted. It is also one encapsulating her familiar poetic traits: the mythical, evident in her reworking of the myth of Eden; the dialectical, in her three-part structuring of voices; and the detached tone, in her speaker's-to borrow from a certain auditor of Glück's Harvard reading (as cited in Vendler, 1980 , p. 305) - "unearthly" observations of human suffering. As such, it is unsurprising that many critics have invested their time and thought to characterize and categorize the 1993-Pulitzer-Prize-winning book since its publication in 1992. Many, like Linda Gregerson (as cited in Bloom, 2010, pp. 109121), have discussed the nature and effects of the tripartite voices. Also many, like Daniel Morris (in the first part of the "Sower against Garden" in The Poetry of Louise Glück), have traced the speaker's emotion/thought trajectory and the sequence literary sources.

However, although such studies have indeed contributed much to our general understanding of the sequence, they left a lacuna: because they were concerned mainly with topical questions, the arguments were conducted at the expense of the individual poems minute details. Within such studies, 
each poem serving as illustration never got its due as a single whole. Here is Gregerson making a point on the anthropomorphic voices of the non-human speakers:

God and the flowers speak with the voice of the human; the human writer has no other voice to give them. The flowers sense, or describe sensation, in unabashedly human terms: "I feel it / glinting through the leaves," says the shaded vine, "like someone hitting the side of a glass with a metal spoon" ("Lamium" 5). They measure aptitude by contrast or analogy with human aptitude: "[T]hings / that can't move," says the rooted tree, "learn to see; I do not need / to chase you through / the garden" ("The Hawthorne Tree" 18); "I am not like you," says the rose, "I have only / my body for a voice" ("The White Rose" 47). God speaks in the voice of an earthly parent who has reached the end of his tether: "How can I help you when you all want / different things" ("Midsummer" 34); "Do you suppose I care / if you speak to one another?" ("April" 20). (as cited in Bloom, 2010, p. 120).

Assembling textual evidence from four different poems, she makes a strong case to her points. Nevertheless, her focus on the nature of the voices forces Gregerson to foregone the minutiae of the poems she quotes from: there is no mention, for example, of the poem's employment of structures, rhythm, or rhetorical devices. Oddly enough, this is also the case with Morris's part-second reading of The Wild Iris, the one in which he ostensibly intends to provide a poem-by-poem closereading of the poems. Take, for example, his entire analysis of the third "Vespers":

Set in August, the third "Vespers" exudes an elegiac quality as it describes a late point in the gardening season, as well as, by analogy, lateness in the sequence of lyric meditations. A commentary on her ambition to transform the literal environment into a symbolic landscape throughout The Wild Iris, the poem takes a retrospective glance at the volume's overarching metaphor of the self when imagined as a speaking flower. Unlike the Shakespearean sonneteer who refused to compare his beloved to a summer's day, the speaker proclaims that she "compared myself / to those flowers" of August (WI 38). We would suspect that, because the speaker acknowledges she has accepted "perishable bliss" as the necessary sign of human difference from God, she would be celebrating the creation of a lyric opening and the temporal interval necessary for storytelling through "foreshadowing," but not here. Instead, the speaker laments her suspicion that by "study[ing] the hawkweed, / the buttercup," her representations of nature are redundant and superfluous, because nature is already a symbolic representation of God's grandeur. "You [God] already know / how like your raiment it [nature] is" (WI 38). Lines such as, "I am uniquely / suited to praise you. Then why / torment me?" and "is pain / your gift to make me / conscious in my need of you [?]" register the persona of Job at his lowest points, a scapegoat whose pain is unredeemed. This "Vespers" refers back to the sixth "Matins," which portrayed the gardener as isolated from other human beings and, therefore, as worse off than the "sick rose," which could at least share its misery by spreading contagion to other members of the species. (2006, pp. 221-222).

Here, Morris traces the human speaker's emotional development up to this point of the sequence; summarizes the poem's content as basically a meta-poem, viz. a poem about poem and elaborates what he means thereafter. He also touches on the poem's theme as he positions it in the intertextual networks of The Wild Iris' prayer sequence and Western literature. With all these, Morris has finished touching the generalities. However, just as we expect him to go further into details, his reading is finished: there is no mention of the poem's internal structure or the contrastive dictions of the poem's beginning and ending.

To redress this, I aspire to initiate a poemcentered study on The Wild Iris. In other words, I intend a study of poetry in its entirety, with detailed attention not only to the themes as expressed by the obvious features, but also as expressed by the various minute aspects. From a consideration of space, time, and 
knowledge constraints, however, on this occasion I present only a reading of the third "Vespers", a poem (together with the other 'prayer poems' in the sequence) which occupies structural and thematic centrality, as Helen Vendler (1995, p. 16) and Morris (2006, p. 201) have noted.

\section{Methodology}

The recent trend in the field of literary study has been to focus on the question of how external determinants shape literary works and in turn how literary works bear records of those external determinants. In the view of many, this trend has shed light on how canonical texts help shape the structure of power in the real world by misrepresenting the others (be that in gender, class, race, west/east, or sexuality terms), paving the way for alternative representations. The present study, by choosing to employ Vendler's critical methodology, does not follow this trend.

This choice does not make the study obsolete, too narrow, or naïve, however, as some would argue. Despite these charges, paying close attention to features of literary works in strictly literary terms continues to be important. Vendler, one of the most prominent critics espousing this view especially in the context of studying a poem, writes:

To understand a poem it's necessary above all to understand its functional stylistic elements; when a scholar-without a profound knowledge of the poet's workswoops in on a single poem to illustrate an ideological point, he or she tends to falsify both the poem and the poet in question. (2015, p. 4).

Intrinsic mode of reading promises an understanding and appreciation of the features ("functional stylistic elements") of literary works.

\section{Premises}

There are several premises adopted here. First, I took as true that a poem consists of mutually important and intertwined content and forms: "Form is content-as-arranged; content is form-as deployed" (1997, p. 14), as Vendler memorably put it. They are mutually entwined, for instance, in the occurrence of what is called verbal mimesis, where the form imitates, and thus, reinforces the content. Content-wise, I also followed Vendler in assuming that the content of a poem is generally human feelings. "It is feelings that are represented by poems, not meaning," she asserted (2003).

Meanwhile, form-wise, I believed that in a poem, not all formal features carry the same weight of significances. In the introduction to her close reading of all 154 Shakespearean sonnets, Vendler wrote, "I wanted to delineate whatever a given sonnet offered that seemed aesthetically most provocative: if there is an interesting change of address, it will be remarked, while a predictable change of address may not be commented on at all" (1997, p. 12). Consequently, in discussing a poem, it is justifiable-if not ideal-that one should focus on features with major significances only.

Next, I assumed (contra Deconstruction) that every poem has a fundamental gestalt; no poem, in other words, is without a central significance and coherence. Vendler betrayed this assumption when she stated that while it is true that Stephen Booth had given a massive contribution to the study of Shakespeare's sonnets, he had also committed a "too ready surrender to hermeneutic suspicion" (1997, p. 13). She considered Booth has failed to decide which of the many overlapping structures he had identified in each sonnet was its "fundamental gestalt" (Ibid). Second to last, I assumed too that every choice implicitly made by the poet is a motivated one.

To understand a poem, the import of the poet's choices must be construed, even if only conjecturally. This assumption is most clearly expressed in Vendler's response to Andrew Butterfield's unfavorable review of Leo Steinberg's Last Supper. Vendler wrote, "[T]he obligation of a critic [is] to mediate, through an informed subjectivity, the totality of the artwork as [s/he] intuits its reasons for being as it is" (1996). 
Finally, I took as true that contexts (be it intertextual, historical, or biographical) are relevant, as long as it throws light, decorously, on the poem's meaning. Ostensible throughout entire body of critical writings, Vendler incorporated contextual information when necessary to support her aesthetic readings. For example, in her reading of Adrienne Rich's "Mother-in-Law", Vendler drew from Rich's biographical facts (a woman, a lesbian, a daughter-in-law, a widow, a younger generation, a mother, a person living alone) to support her decision to identify the speaker as the poet herself (2010, pp. 214-217).

\section{Procedure}

Vendler's analytical procedure, most apparent in her shorter analysis as can be found in Dickinson (2012) and The Art of Shakespeare's Sonnets (1997), can be grouped into two steps. First, she would analyze the surface aspects of the poem's title, body, and internal structure ${ }^{3}$ in order to formulate the poem's content/theme as well as to establish the poem's 'mise-en-scéne' (personae and settings). ${ }^{2}$ Secondly, she would continue to analyze and interpret the poem's minute yet significant formal elements (tenses, diction, mechanics, syntax, rhythm, , and imagery) with regards to the theme already formulated in the first step. Although in its written form Vendler's analysis does not always come in this order as she is not only concerned in writing logically but also beautifully, the underlying order is such.

In the present paper, I follow this two-step analytical procedure faithfully. First, I analyze the third "Vespers"'s title, body, and internal structure to formulate its content/theme and 'mise-en-scéne'. Secondly, I analyze its formal aspects and interpret them in relation to the theme.

\section{Discussion}

As the twenty-line colloquial-sounding poem is quite short, here I quote it whole:

\section{Vespers}

More than you love me, very possibly you love the beasts of the field, even,

\author{
possibly, the field itself, in August dotted \\ with wild chicory and aster: \\ I know. I have compared myself \\ to those flowers, their range of feeling \\ so much smaller and without issue; also to \\ white sheep, \\ actually gray: I am uniquely \\ suited to praise you. Then why \\ torment me? I study the hawkweed, \\ the buttercup protected from the grazing \\ herd \\ by being poisonous: is pain \\ your gift to make me \\ conscious in my need of you, as though \\ I must need you to worship you, \\ or have you abandoned me \\ in favor of the field, the stoic lambs turning \\ silver in twilight; waves of wild aster and \\ chicory shining \\ pale blue and deep blue, since you already \\ know \\ how like your raiment it is. \\ (Glück, 2014, p. 280)
}

\section{Obvious Features}

To begin with, poem's title comes from the PIE word 'wes-pero' (evening, night) which descended to the Greek's 'hespero' and Latin's 'vespera' (evening), and further descended into the Old French 'vesper' (evening, nightfall). From there, the word entered the English language first in $14^{\text {th }}$ century, initially only carrying the meaning of "evening star." In $17^{\text {th }}$ century, however, the sense "evening" and "evening prayer" also catered themselves also to the word. In specific, this prayer specifically points to the liturgical tradition of Catholicism, vespers (or evensong) being one of the seven canonical hours of the Catholic daily mass prayer (the other being prime, terce, sext, nones, compline, lauds/matins) (Vespers). In the poem's title, both the original sense of "evening" and the later sense of "prayer" are relevant. The first reveals that evening is the time when the poem is uttered while the second reveals that the poem is a prayer: a one-way conversation between a human being to his/her God. Meanwhile, the religiousassociated sense suggests a possible link to a body of devotional poetry closely associated with Christianity. However, such link cannot be ascertained yet as the theme becomes clear 
only in the body of the poem, to which I now turn.

One question immediately arises upon reading the poem's body: how to denote the speaker: he or she? The poem does not provide any answer, but a consideration of the poem in the context of The Wild Iris as whole does, specifically the evening prayer poems. In the first "Vespers", the speaker says:

Once I believed in you; I planted a fig tree. Here, in Vermont, country

of no summer. It was a test: if the tree lived, it would mean you existed.

[...]

[H]ere, we barely see

the hem of your garment. I have to discipline myself

to share with John and Noah the tomato crop.

(Glück, 2014, p. 278)

There are two things of note here. First, as with the speaker, Glück had also lived in Vermont. Second, the John and Noah are names of Glück's husband at the time she was living in there, and of her son. Therefore, the justification to identify the speaker with the poet herself is indeed strong. To further ascertain the fact that the proper names really refer to Glück's husband and son, and not to biblical figures, I append a quotation from another poem, "Heaven and Earth", spoken by the human speaker:

John stands at the horizon: he wants
both at once, he wants
everything at once.
[...]
How can I leave my husband
standing in the garden
dreaming this sort of thing,
(Glück, 2014, p. 274)

Here, John refers to the poet's husband and that, by association, Noah refers to her son.
The speaker of the poem is Glück's herself, hence, a female.

That established, now I turn to the poem's meaning. In the first sentence, the human speaker states that she knows God loves the other creations more than He loves her. She then continues in the second sentence with a case-making for her questioning of God's act: although, after comparing herself to other creations (sheep, chicory, aster), she is sure that she is better than them, God still loves her less. This second sentence combined with the first, the implication becomes obvious: the speaker believes that this 'unconditional love' from God to other inferior creations must be the source of her suffering. This is even more evident as soon as the explicit question, half serious, half rhetorical, which is the turning point of the poem, appears: "Then why/ torment me?" Descending from the climax, in the fourth sentence the speaker imparts her on-going activity: presumably from a feeling of dissatisfaction, she compares herself again with the other creations. First, she compares herself to new kinds of vegetation, hawkweed and buttercup (both poisonous and inedible plants), which seems to her to be content with their undisturbed and painless state. Next, although only implicit, she then compares herself to creatures she already observed earlier. As a result of these comparisons, the speaker comes up with two alternatives for God's rationale: one, she suffers because God gives pain to make her realize her need of Him; the other, she suffers because God has abandoned her in favor the other creations. When this meaning is pared down, the internal structure of the poem becomes visible: the third "Vespers" is structured on the three comparisons (both implicit and explicit) that the speaker does on herself and the other creations regarding their relationship with God. It is represented as follows:

Table 1. the Internal Structure of the Third "Vespers"

\begin{tabular}{|c|c|c|c|}
\hline \multirow{2}{*}{ Sentence } & \multicolumn{2}{|c|}{ Comparisons } & \multirow{2}{*}{ The speaker's conclusions } \\
\hline & Order & Other Creations & \\
\hline $1^{\text {st }}, 2^{\text {nd }}, 3^{\text {rd }}$ & $\begin{array}{l}1^{\text {st }} \\
\text { (in line } 5-9)\end{array}$ & $\begin{array}{l}\text { beasts/sheep, } \\
\text { aster and chicory }\end{array}$ & $\begin{array}{l}\text { God loves the other creations more (in line 1-5). } \\
\text { She is better than the other creation (in line 5-9). }\end{array}$ \\
\hline
\end{tabular}




\begin{tabular}{|c|c|c|c|}
\hline & & & $\begin{array}{l}\text { As a logical extension of this conclusion, she asks God: } \\
\text { "Then why/ torment me?"(in line 9-10). }\end{array}$ \\
\hline \multirow[t]{2}{*}{$4^{\text {th }}$} & $\begin{array}{l}\text { Second } \\
\text { (in line 10-11) }\end{array}$ & $\begin{array}{l}\text { buttercup and } \\
\text { hawkweed }\end{array}$ & $\begin{array}{l}\text { God gives pain to make her aware of her need of God, } \\
\text { since unlike the seemingly content buttercup and } \\
\text { hawkweed, she does not have a protective system (in } \\
\text { line } 12-15 \text { ). }\end{array}$ \\
\hline & $\begin{array}{l}\text { Third } \\
\text { (implied) }\end{array}$ & $\begin{array}{l}\text { lambs, chicory } \\
\text { and aster }\end{array}$ & $\begin{array}{l}\text { Her pain comes from the fact that God's abandons her } \\
\text { in favor of the other creations (in line } 16-20 \text { ). }\end{array}$ \\
\hline
\end{tabular}

For one, the above paraphrase and structure flesh out the poem's settings and personae. In the pasture/garden-like autumnal cosmos of the third "Vespers", in addition to God and human, there are other personae too. They are the other creations, namely the animals ("beasts"/"sheep"/"lambs) and vegetation ("chicory and aster", the poisonous "buttercup" and "hawkweed"). The paraphrase tells us too that within this hierarchical cosmos (at least according to the speaker) being abandoned by God equals pain. As a result, while God the creator presides over all, all creations compete to be the apple of His eyes.

The paraphrase and structure also reveal the central theme of the poem. As these show, the poem centers on the speaker's pining to know the reason why God, despite all her selfperceived qualities (which she deems superior compared to the other creations'), let her suffer. Pining, then, is the theme. That Glück decided to take up this perennial theme here, one that the anonymous writer of Job, and poets such as Herbert and Dickinson have also taken up is made even more convincing by the fact that pining is indeed one of the major themes in The Wild Iris. In his reading of the poem, Morris also saw the resemblance of the speaker of the third "Vespers" to Job. However, he found a different thematic import: instead of focusing on the pining, he contended that theme is the suffering itself (2006, pp. 205206). This I must differ from: although the feeling of suffering is closely related to the poem, and although it is also one thematic preoccupation of the sequence as whole, this poem does not preoccupy itself with analyzing and expressing suffering. As I hope my reading shows, it is the pining to find explanation for the speaker's suffering that the poem is about.
Finally, a surface reading of the poem's body shows that alongside pining, there are two others attendant feelings: the antithetical feelings of conviction and doubt the speaker feels with regards to her superiority over the other creations. These feelings-evident when

the speaker begins the comparisons-are the direct consequences of her pining: since God offers no answer, she is left to her own device to come up with her own explanation, resulting in answers at once convincing and unconvincing; and they act to highlight the extent to the speaker's pining. All these are revealed by the poem's obvious features. However, there is more to the doubt, conviction, and pining of the speaker in third "Vespers" than what first meets the eyes.

\section{Minute Features}

When given a closer look, the poem opens so many dynamics between its theme and forms. The tenses and the present action of the speaker, to start somewhere, reveal the events before the poem was set into motion. Initially, the speaker felt content with her state, implicit in the fact that poem as such exists in the first place (Had she been always content, the poem would have not existed as she would not have any reason to propel her into speech). On top of that, her present accusation of God having abandoned her ("have you abandoned me") suggests also that there was a time when she was not abandoned, meaning a time when she was content. After this initial state, the status quo was disturbed: torment, pain, and discontentment came. The use of present tense in the following part (which does not only indicate that what happens is happening only just now, but also suggests that it has happened, repeatedly, before) confirms this: 
torment me?

[...]

is pain

your gift to make me

conscious in my need of you

She did not immediately speak the third "Vespers", however. Instead, she first asks God for an explanation. That she did this is implicit in what she does now: the act of looking for an answer entails the condition of having a question, and the act of answering one's own question implies that one's initial effort at asking other-in her case, asking God-came to no avail. Only after her question was met with constant silence did she begin to speak the poem. Represented graphically, this antecedent scenario is as follows.

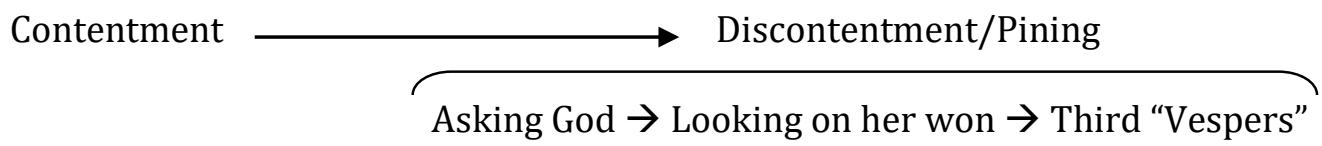

How does this relate to the theme? By displaying her emotional journey, from losing her initial content state to her present discontent without knowing why, from futilely asking God to desperately resort to an equally vain effort of comparisons, the antecedent scenario gives more weight and volume to the speaker's pining, and thus, make it more believable.

A similar emphatic effect is also produced by the expression of the conviction-doubt dynamics experienced by the speaker in relation to the answer to her pining and also to her sense of superiority over the other creations. With regards to the former, this dynamic is expressed in the poem's denotation, mechanic, rhythm, and syntax. In the beginning of the poem, conviction and doubt are both present:

\section{More than you love me, very possibly you love the beast of the field, even, possibly, the field itself, in August dotted with wild chicory and aster: \\ I know.}

Here the conviction-expressing intensifiers "very" and "even", which are then counterbalanced by the doubt-expressing hedge "possibly" - appearing twice with a greater intensity in the second)-tell us as much. Nevertheless, conviction seems to have the more weight at this point. For one, the poem starts headily with the thoracic "More than" (/ X), which gives a strong rhythmical emphasis when it is put in the beginning of a poem. ${ }^{4}$ Also in this part, there is the strong and short assertion of "I know", which is further reinforced by the use of colon (":"), indicating not only that what comes before it is what the human speaker knows, but also that what comes after the colon gets the more emphasis. This propensity to conviction is even more ostensible in the next sentence:

\author{
I have compared myself \\ to those flowers, their range of feeling \\ so much smaller and without issue; also to \\ white sheep, \\ actually gray: I am uniquely \\ suited to praise you.
}

The conviction in her speech is exponentially emphasized. There is her use of the emphatic adverb "uniquely." There is also, the colon "like a sign on the highway, announcing that something important is coming" ("Semicolons, Colons, and Dashes", n.d.), underlining the statement of superiority that follows it; hence, a bolder mark of conviction. And then, there is her use of subtle intensification. In the phrases she uses to modify the "[flowers'] range of feeling", she moves from "so much smaller", which is a less derogatory label, to "without issue", a completely derogatory one, betraying how much she thinks of the flowers as insignificant, and at the same time, showing how convinced she is of her superiority. ${ }^{5}$ Continuing the increasing conviction, her feeling is brought to the climax when all doubt vanish in the rhetorical question of the third four-word sentence. 
However, after the climax comes the descent: in the last and longest sentence of the poem (which sits in stark contrast with the brevity of the previous sentence, corresponding to the speaker's dramatic change of inner state), doubt abruptly reappears. The two independent clauses making up this part ("is pain [...]" and "have you [...]"), expressing the possible reasons God torments her, are joined with the conjunction "or", pointing to the alternatives, and thus, doubt faced by the human speaker. In contrast, the anomalous full stop at the end of the sentence in place of a question mark shows her conviction. Now, therefore, the two antithetical feelings come into a perfect balance, which is quite like the speaker's state at the beginning of the poem. The question form shows her doubt; the period her conviction: she is questioning, but not really questioning; she is in doubt, but also quite sure. This mixture of feelings at the end of the poem's little dramatic arch highlights the speaker's pining.

Meanwhile, the drama of conviction and doubt in relation to the speaker's sense of superiority over the other creations is enacted by the poem's connotations, rhythm, and imageries. There is a suggestive pattern of lexical contrast emerging as the third "Vespers" progresses which corresponds to the speaker's feelings. In the beginning, as a result of the first comparison she has done to look for an answer, she is sure of her superiority.

Aside from the meaning of her statement, this is evident by the nouns she chooses to denote as well as the adjectives she uses to label the other creations. For the animals, at the start she chooses the word "beasts", a blatantly pejorative word. Then, as the poem moves and almost reaches its climax, she modifies the noun to "sheep", a more positive (as well as more specific) word than the first, signaling her growing doubt. It still, however, carries a negative value in that it suggests "a timid defenseless creature" or "one easily influenced or led" (Sheep [Def. 2.]). Her correction of the adjectival modifier for "sheep" from one carrying positive value ("white") to one carrying a clearly negative one ("gray") similarly expresses this.
After the turning point of the poem, however, her conviction disappears, and doubt reigns over her: at first labeling the animals as "beasts" and "sheep", here, in a striking contrast, the speaker finally denote them as "lambs" with its association with "dear" and "gentle" (Lamb [Def. 2.]) and "innocence" (Ferber, 200, p. 191) as well as with the religious tradition of Christianity (Christ is referred as the lamb of God). ${ }^{6}$ On top of that, the noun's modifiers are also transmuted from the patronizing "actually gray," suggesting dullness in addition to her firm conviction (to the point of assuming such tone to God), to now the admiring "silver" and "stoic." Lastly, the mesmerizing visual imagery the speaker uses to describe the lambs' color under the evening light bestows a lustrous beauty. Alike import from a comparable imagery is also found in another poem from The Wild Iris, "Love in Moonlight." Only, here, it is moonlight—twilight's kin-which bestows beauty:

Outside, a summer evening, a whole
world
thrown away on the moon: groups of
silver forms
which might be building or trees, the
narrow garden
where the cat hides, rolling on its back
in the dust,
the rose, the coreopsis, and in the dark,
the gold
$\quad$ dome of the capitol
converted to an alloy of moonlight
(Glück, 2014, p. 261)

A parallel arch can also be observed in the context of the vegetation (and the field). In the beginning, the speaker uses the verb "dotted" to link "field" with "chicory"/"aster", a word which carries a negative value. The image produced by such a phrase, i.e. a field occupied by thriving speck-like chicory and aster in an otherwise spotless green expanse, is a far cry from an image one usually associated with beauty. A diptych of this image and the image of beauteous moonlight discussed above makes it clear that the former, in contrast with the moonlight image, is used to suggest the unbeautiful. "Chicory" and "aster" are also modified by the adjective "wild" which neutrally means "living in a state of nature and 
not ordinarily tame or domesticated," but can also mean "not subject to restraint or regulation", "marked with turbulent agitation", "uncivilized", and "barbaric" (Wild). These two emphasize the meaning of the speaker's obvious utterances about her superiority. However, after the initial sentiment, unlike the progress seen with regards to the animal, here, there is no middle transitory ground. Instead, following the highpoint of the poem, the vegetation is fully elevated as the speaker completely doubts her superiority. Now, she describes the flowers as "shining", and even more striking, as resembling God's "raiment", a superlative label in the poem's cosmos. Similarly, when the same part is considered in the larger picture of imagery, that the speaker has completely lost her confidence is clear: "waves of wild aster and chicory shining/ pale blue and deep blue." Ocean waves and flower beds are conflated here, resulting in an image which is visually beautiful, an image of flowers transformed into symphonic bluish waves exhibiting their different shades. On top of that, the color chosen (or the blue flowers chosen for that matter $)^{7}$ and twice repeated to a euphonic effect, first in the iamb of "pale blue" (X/) and then in the anapest of "and deep blue" (X X /) also adds to intensify this quality. By the end of the poem, when seen in the context of its connotations and imageries, the speaker has experienced an emotional journey from a complete conviction to total doubt with regards to her superiority. Here one can argue that when seen from a different angle, this doubt is a conviction, not on her superiority but on the other creations' superiority. If this is the case, then, it is a strong justification for God's to abandon the speaker, and hence, the answer to her pining. However, when considered against the poem as whole, particularly the significance of the poem's denotation, mechanic, rhythm, and syntax already discussed above, this is clearly not the case. The commingling of conviction and doubt, as well as the journey from the former to the later, instead, accentuate the speaker return to her former state of not knowing God's rationale, of pining. In the end, she comes full circle to what she was right before the poem began: from discontent to discontent, from pining to pining.

\section{Conclusion}

As we have seen, the third "Vespers" is a poem about pining and its attendant feelings of doubt and conviction. In particular, here the pining is to know the reason for her discontent. This theme is revealed both by the obvious features and by its various minute features.

Vendler espouses that there are so much more to a poem than the immediately perceivable features; the details, too, are significant in that they can emphasize, modify, extend, and/or meaningfully contradict the imports gained from the obvious features. Combined, both of these facets make up the interconnected whole which is the sum of a poem, as we have seen in the case of the third "Vespers" with its convinced, doubtful, and pining speaker.

\section{Notes}

1. Vendler did a somewhat balanced analysis of general topics and of specific poems in "Flower Power", a review of The Wild Iris in The New Republic (later collected in Soul Says). However, the nature of her medium precluded her from going into enough details. Her review, furthermore, did not include any mention of the third Vespers.

2. Although Vendler never discussed this division, nor mentioned the terms "obvious" and "minute", these are implicit in her critical writings.

3. In A. R. Ammons' poem of finding moral lesson in nature (as quoted in Vendler, 2010, p.372), "The City Limits", there apparent the logical 'When This - Then That' pattern organizing the whole poem. When seen through this structure, nothing in the poem is left out; everything falls into places easily. It is this kind of organizing pattern that this study called the internal structure of a poem. Vendler offers the only definition I know of this concept when she defines it as "the intellectual or logical shapes into which its thoughts are dynamically organized" (2010, p.86). 
4. A well-known example of the case is the beginning of John Donne's "Holy Sonnet 10."

5. This technique has often been used to serve the same purpose. A passage from Camille Paglia unfavorable view of Marjorie Garber's book, where she makes a point about Garber's lack of substation, can serve as an example:

The remarks about Madonna, attributed to another academic, are fragmentary and distorted; the description of Michael Jackson doesn't move us beyond Entertainment Tonight; the passing sentences about Prince, about whom Garber clearly knows nothing, are quotes from published sources. The female illusionist Jim Bailey is barely mentioned, and the brilliant Jimmy James not at all.

(1992, p. 99).

The movement from "fragmentary and distorted" to "doesn't move us beyond" to "the passing sentences" to "published sources" to "barely mentioned", and finally to "not at all" demonstrates the use of a similar technique, though in a more elaborate manner.

6. A similar technique can be found in "Sonnet 144" by Shakespeare, as Vendler (1997, p. 606) has shown us.

7. Blue itself has been associated with heavenly qualities (Farber, 2007, p. 31), one of which is beauty.

\section{References}

Ferber, Michael. (2007). A Dictionary of Literary Symbols. $2^{\text {nd }}$ ed. Cambridge: Cambridge University Press.

Gregerson, Linda. (2010). "The Sower against Garden" in Contemporary Poets. Ed. Harold Bloom. New York: Bloom's Literary Criticism.

Glück, Louise. (2014). Poems: 1962-2012. New York: Farrar, Straus and Giroux.

Lamb [Def. 2.]. (n.d.). In Merriam-Webster Collegiate Dictionary. Retrieved March 3,
2019, from https://www.merriamwebster.com/dictionary/lamb

Morris, Daniel. (2006). The Poetry of Louise Glück: $A$ Thematic Introduction. Columbia: University of Missouri Press.

Paglia, Camille. (1992). Sex, Art, and American Culture. New York: Vintage Books.

"Semicolons, Colons, and Dashes." (n.d.). The John A. Dutton e-Education Institute. Retrieved April 25, 2019, from https://www.e-education.psu.edu/ styleforstudents /c2_p5.html

Sheep [Def. 2.]. (n.d.). In Merriam-Webster Collegiate Dictionary. Retrieved March 3, 2019 from https://www.merriamwebster.com/dictionary/sheep

Vendler, Helen. (2012). Dickinson: Selected Poems and Commentaries. Cambridge: Harvard University Press.

- - (2010). Poems, Poets, Poetry: An Introduction and Anthology. $3^{\text {rd }}$ ed. Boston: Bedford/St. Martin's.

-_. (1980). Part of Us, Part of Nature: Modern American Poets. Cambridge: Harvard University Press.

_- . (1995). Soul Says. Cambridge: Harvard University Press.

- - (1997). The Art of Shakespeare Sonnets. Cambridge: Harvard University Press.

- - (2015). The Ocean, the Bird and the Scholar. Cambridge: Harvard University Press.

- - (1996, October). "The Booby Trap." The New Republic, pp. 33-37.

- - (2003, January). "Yeats and Form." Lannan Podcasts. Lannan Library. Retrieved from http://www.lannan. org/ events/helen-vendler

Vespers. (n.d.). In Online Etymology Dictionary. Retrieved March 3, 2019, from http://www.etymonline.com/index.php ?term=vesper

Wild. (n.d.). In Merriam-Webster Collegiate Dictionary. Retrieved March 3, 2019, from https://www.merriam-webster. com/ dictionary/wild 